Artikel Penelitian

\title{
Pengaruh Ekstrak Etanol 90\% Daun Sirih Merah terhadap Kadar Malondialdehid (MDA) dan Superoksida Dismutase (SOD) Mencit Tikus yang Dipapar Asap Rokok
}

\author{
S.A. Prayitno ${ }^{1 *}$, Joni Kusnadi², E.S. Murtini²
}

1 Jurusan Teknologi Pangan, Universitas of Dr. Soetomo, Surabaya, Jawa Timur, Indonesia, 60118

2 Jurusan IImu dan Teknologi Pangan, Universitas Brawijaya, Malang, Jawa Timur, Indonesia, 65145

\section{INFO ARTIKEL}

\section{Riwayat Artikel}

Direvisi 24 Mei 2018

Diterima 11 Juni 2018

Tersedia online 21 November 2018

* Email penulis korespondensi:
sutrisnoadi2007@gmail.com

\section{ABSTRAK}

Cigarette smoke is a source of free radicals which cause human body organs damage when it is exposed. Cigarette smoke as a medium that causes oxidative stress that has the potential to cause oxidative damage. In addition, cigarette smoke also has potency to reduce SOD (Superoxide dismutase) levels and increase MDA (Malondialdehyde) levels especially in lung tissue. To control or prevent the presence of free radicals in the body, antioxidant compounds are needed by the body. The purpose of this research is to know the effect of the extract of red betle on SOD and MDA content of mice exposed to cigarette smoke. Red betle was extracted by maceration using ethanol. The exposed mice were treated with red betle extract for 14 days. Lung tissue of the mice was analyzed SOD and MDA conentrations. The results showed that SOD levels tend to increase and decrease MDA levels in mice test animals exposed to cigarette smoke. The optimal dose to decrease MDA levels and increase SOD is 230.4 $\mathrm{mg} / \mathrm{g}$ weight/day. Histopatology result showed there is different figure of lung tissue (alveoli) before and after red betle extract treatment.

Keywords: Red betel, ethanolic extract, malondialdehyde (MDA), superoxide dismutase (SOD)

Asap rokok adalah sumber radikal bebas yang dapat mengakibatkan rusaknya organ dalam tubuh manusia apabila terpapar. Asap rokok sebagai media penyebab terjadinya stress oksidatif yang berpotensi menyebabkan kerusakan oksidatif. Selain itu, asap rokok juga berpotensi dalam menurukan kadar SOD (Superoksida Dismutase) dan meningkatkan kadar MDA (Malondialdehida) terutama pada jaringan paru. Untuk mengendalikan atau mencegah adanya radikal bebas ke dalam tubuh maka senyawa antioksidan dibutuhkan oleh tubuh. Tujuan penelitian adalah adalah mengetahui pengaruh ekstrak etanol daun sirih merah terhadap kadar SOD dan MDA mencit yang dipapar asap rokok. Daun sirih merah diekstrak menggunakan metode maserasi. Mencit yang telah dipapar asap rokok diberi perlakuan ekstrak selama 14 hari. Jaringan paru-paru dianalisis kadar MDA dan SOD. Hasil penelitian menunjukan kadar SOD cenderung mengalami peningkatan dan kadar MDA mengalami penurunan pada hewan uji mencit yang dipapar asap rokok. Dosis yang paling optimal untuk menurunkan kadar MDA dan menaikan SOD adalah dosis 230,4 mg/g bb/hari. Hasil histopatologi menunjukkan terdapat perbedaan gambaran jaringan paruparu (alveoli) sebelum dan setelah perlakuan ekstrak.

Kata Kunci: Sirih merah, ekstrak etanol, malondialdehid (MDA), superoksida dismutase (SOD) 


\section{Pendahuluan}

Asap rokok adalah sumber radikal yang dapat mempengaruhi aktivitas enzim dalam tubuh sehingga dapat menyebabkan berbagai penyakit seperti kardiovaskular dan mempengaruhi sistem pernapasan, syaraf, dan imun [1, 2, 3, 4]. Asap rokok mengandung senyawa campuran (nikotin, tar dan 3,4-benzopiren, $\mathrm{CO}, \mathrm{CO}_{2}$, $\mathrm{NO}$, amonia, dan sulfur) yang bersifat karsinogenik dan menyebabkan kematian $[5,6]$. Paparan asap rokok menurunkan kadar gluthatione (GSH) paru, penurunan aktivitas gluthatione peroksidase dan glucose-6-phosphate dehydrogenase (G6PD) [7].

Asap rokok dapat penyebab timbulnya stres oksidatif yaitu ketidakseimbangan antara prooksidan dengan antioksidan. Jumlah prooksidan di dalam tubuh melebihi kapasitas untuk dinetralisir sehingga prooksidan berpotensi menyebabkan kerusakan oksidatif [8]. Stres oksidatif disebabkan asap rokok yang merusak membran sel lipid sehingga terbentuk radikal lipid baru dan bereaksi dengan oksigen yang membentuk senyawa radikal peroksil, peroksida dan malondialdehid (MDA) [9]. Peroksidasi lipid adalah reaksi oksidasi berantai yang menghasilkan radikal bebas sehingga menginisiasi peroksidasi lebih lanjut dan menyebabkan rantai asam lemak membran sel terputus menjadi senyawa malondialdehid [10].

Asap rokok dapat juga merusak jaringan dengan meningkatnya kadar MDA dan menurunnya kadar enzim superoksida dismutase (SOD). Kerusakan sel paru-paru terjadi pada asam lemak tidak jenuh fosfolipid membran sel, sehingga terbentuk peroksida lipid. Pada akhir rangkaian degradasi peroksida lipid menghasilkan senyawa etana, pentana dan MDA. Senyawa MDA dapat dijadikan biomarker peningkatan peroksida lipid akibat radikal bebas. Enzim SOD adalah enzim endogen untuk meredam radikal bebas [11].

Efek radikal bebas dapat dicegah dengan mengkonsumsi makanan atau minuman yang mengandung antioksidan. Penggunaan daun sirih merah sebagai sumber antioksidan untuk menghambat radikal bebas masih jarang dilakukan. Penelitian ini mengkaji potensi sirih merah (Piper crocatum) sebagai antioksidan alami. Antioksidan alami merupakan sumber antioksidan sebagai bentuk perlindungan kesehatan terhadap radikal bebas [12]. Ekstrak daun sirih merah dengan kandungan senyawa yang berpotensi sebagai antioksidan alami selanjutnya bisa diaplikasikan untuk meningkatkan kadar SOD dan MDA akibat adanya paparan asap rokok.

\section{Bahan dan Metode}

\subsection{Bahan}

Bahan utama yang digunakan adalah daun sirih merah segar berasal dari Desa Menadi, Kabupaten Pacitan, Jawa Timur. Etanol 90\% (teknis) digunakan sebagai pelarut pada proses ektraksi. Hewan uji yang digunakan adalah mencit putih jantan galur balb/c yang berumur 2,5-3 bulan (berat badan 19-25 gram) dengan pakan (BR-1) dan air minum mencit. Rokok yang digunakan adalah rokok kretek tanpa filter (Gudang Garam). Bahan yang digunakan analisis MDA dan SOD adalah PBS (Phosphate-Buffer Saline), Xantine (MP), Xantine Oxidase (Sigma), NTB (Nitroblue Tetrazolium) (KPL), TCA (Trichloroacetic Acid) 100\% (Merck), Na Thiosulfat 1\% (Sigma) dan $\mathrm{HCl} 1 \mathrm{~N}$ (Merck). Uji in vivo dan histopatologi memerlukan organ paru-paru mencit, BNF (Buffer Normal Formalin) 10\%, alkohol (70, 80, 90, dan 95\%), alkohol absolut (I, II, dan III) (Merck), xylol (I, II, III) (Merck), parafin, hemaktosilin (Merck), dan eosin (Merck).

\subsection{Preparasi Sirih Merah}

Daun sirih merah disortasi dan dicuci dengan air mengalir agar debu dan kotoran hilang sebelum dilakukan pengeringan. Pengeringan menggunakan oven suhu $40^{\circ} \mathrm{C}$ selama $24 \pm 2$ jam. Setelah kering, daun sirih merah dihaluskan menggunakan alat penggiling dengan disaring dengan saringan berukuran 90 mesh.

\subsection{Ekstraksi Sirih Merah}

Metode ekstraksi menggunakan prosedur Prameswari dan Widjanarko [13] yang dimodifikasi. Metode ekstraksi menggunakan maserasi dengan merendam serbuk dalam pelarut etanol $90 \%$ dengan perbandingan $1: 8(\mathrm{~b} / \mathrm{v})$. Ekstraksi dilakukan selama 3 hari dengan erlenmeyer tertutup dimana erlenmeyer ditempatkan pada rotary shaker selama 3-4 jam dan didiamkan selama 24 jam. Kemudian, dilakukan penyaringan dan pengganti pelarut baru dengan volume yang sama. Filtrat yang sudah diperoleh dipekatkan menggunakan rotary evaporator suhu $40^{\circ} \mathrm{C}$ pada kecepatan $40-45 \mathrm{rpm}$.

\subsection{Perlakuan Hewan Uji}

Mencit diaklimatisasi (penyesuaian diri dengan lingkungan) selama satu minggu, diberi pakan dan minum secukupnya (ad libitum). Berat badan mencit saat awal dan saat sesudah adaptasi ditimbang agar dapat terpantau beratnya (19-25 gram). Jumlah yang digunakan adalah sebanyak 24 ekor yang dibagi dalam 6 kelompok (tiap kelompok ada 4 ekor). Penentuan jumlah mencit dalam kelompok dihitung berdasarkan rumus Federer, yaitu $(n-1)(t-1) \geq 15$. 


\subsection{Perlakuan Pemaparan Asap Rokok}

Prosedur ini dilakukan berdasarkan penelitian Adyttia, dkk. [14]. Pemaparan asap rokok dilakukan setiap pagi pukul 08.00 WIB menggunakan 2 batang rokok dan dilakukan setiap 15 menit sampai rokok habis. Pemaparan asap rokok pada mencit dilakukan selama 14 hari pada kotak pemaparan asap dengan ukuran 35,8×28,5×22,5 cm yang dilengkapi dengan lubang kecil sebagai tempat memasukan asap rokok. Cara memperoleh asap adalah dengan membakar rokok dan sambungkan dengan pipa kemudian dihisap (disedot) dengan spuit $50 \mathrm{~mL}$ dan dihisap 10 kali hisapan. Pemaparan asap rokok dilakukan pada semua kelompok kecuali pada kelompok negatif (A1) selama total waktu 2 jam. Satu jam setelah pemaparan asap rokok, mencit diberi ekstrak etanol $90 \%$ daun sirih merah sesuai variasi dosis (A3, $A 4$, dan $A 5)$ dan kontrol vitamin $E(A 6)$. Pada penelitian ini digunakan kontrol posifif (A2) dimana mencit dipapar dengan asap rokok dan tanpa pemberian ekstrak.

\subsection{Penetapan Dosis Uji Ekstrak Etanol dan Vitamin E}

Dosis yang dihitung berupa dosis ekstrak etanol sirih merah dan dosis vitamin E. Dosis ekstrak etanol yang dipakai untuk perlakuan ada tiga dosis awal perhitungan. Dosis tersebut adalah dosis rendah $57,6 \mathrm{mg} / 25 \mathrm{~g} \mathrm{bb} / \mathrm{hari}$, dosis sedang $115,2 \mathrm{mg} / 25 \mathrm{~g} \mathrm{bb} / \mathrm{hari}$ dan dosis tinggi $230,4 \mathrm{mg} / 25 \mathrm{~g}$ bb/hari. Adapun dosis vitamin E yang digunakan adalah $0,86 \mathrm{mg} / \mathrm{g}$ bb/hari mencit.

\subsection{Analisis Kadar Malonaldehida (MDA)}

Prosedur penelitian Sholichah, dkk. [15] digunakan untuk menganalisis kadar MDA. Analisis kadar MDA pada jaringan organ paru-paru dilakukan setelah masa perlakuan selama 14 hari. Hasil pengukuran MDA dinyatakan dalam $\mathrm{ng} / \mathrm{mL}$. Paru-paru sebanyak $100 \mathrm{mg}$ dipotong kecil-kecil lalu digerus dalam mortar (homogenisasi) dan ditambahkan $1 \mathrm{~mL}$ akuades. Homogenat dipindahkan ke dalam tabung mikro dan sentrifugasi pada kecepatan $8000 \mathrm{rpm}$ selama 20 menit dan diambil supernatannya. Campuran $100 \mu \mathrm{L}$ supernatan, $100 \mu \mathrm{L}$ Na tiosulfat $1 \%, 100 \mu \mathrm{L} \mathrm{TCA} \mathrm{100 \% ,} \mathrm{dan} 250 \mu \mathrm{L} \mathrm{HCl}$ $1 \mathrm{~N}$ digunakan untuk deproteinasi (setiap penambahan reagen larutan dihomogenkan dengan vortex). Kemudian, campuran tersebut disentrifugasi pada 3500 rpm selama 10 menit. Supernatan yang terbentuk diambil dan ditambahkan $3500 \mu \mathrm{L}$ akuades. Setelah itu, supernatan diinkubasi dalam waterbath pada suhu $100^{\circ} \mathrm{C}$ selama 30 menit dan didinginkan pada suhu ruang. Absorbansi sampel diukur pada panjang gelombang $532 \mathrm{~nm}$.

\subsection{Analisis Kadar Superoksida Dismutase (SOD)}

Kadar SOD ditentukan berdasarkan prosedur Sholichah, dkk. [15]. Aktivitas SOD dilakukan pada jaringan paru-paru mencit setelah perlakuan selama 14 hari. Hasil pengukuran SOD dinyatakan dalam U/mL. Paru-paru sebanyak $100 \mathrm{mg}$ gram dipotong kecil-kecil dan digerus dalam mortar (homogenisasi). Kemudian, sampel ditambahkan $1 \mathrm{~mL}$ PBS. Homogenat dipindahkan ke dalam tabung mikro dan sentrifugasi pada kecepatan $8000 \mathrm{rpm}$ selama 20 menit dan diambil supernatannya. Campuran antara $100 \mu \mathrm{L}$ xanthine, $100 \mu \mathrm{L}$ xanthine oxidase, dan $100 \mu \mathrm{L}$ NTB ditambahkan $100 \mu \mathrm{L}$ supernatan. Campuran tersebut diinkubasi pada suhu $30^{\circ} \mathrm{C}$ selama 30 menit hingga terjadi perubahan warna menjadi ungu, kemudian disentrifuge dengan kecepatan $3500 \mathrm{rpm}$ selama 10 menit. Supernatan diambil dan ditambah dengan PBS $3500 \mu \mathrm{L}$, selanjutnya dilakukan pengukuran absorbansi pada panjang gelombang $580 \mathrm{~nm}$.

\subsection{Histopatologi Paru-Paru Mencit}

Analisis histopatologi paru-paru mencit didasarkan pada prosedur Abdulla dkk [16] dan Muntiha [17].

\subsubsection{Fiksasi Paru-Paru}

Sediaan organ paru-paru direndam dalam larutan BNF 10\%. Kemudian, dilakukan pemotongan (trimming) dengan ketebalan $\pm 3 \mathrm{~mm}$ dan dimasukkan ke dalam kaset.

\subsubsection{Dehidrasi}

Jaringan yang berada di dalam kaset dimasukkan ke dalam tissue processor untuk dilakukan dehidrasi. Proses dehidrasi dilakukan menggunakan alkohol dengan konsentrasi bertingkat yang terdiri dari alkohol $70 \%, 80 \%, 90 \%, 95 \%$, alkohol absolut I, alkohol absolut II dan alkohol absolut III. Selanjutnya, dijernihkan dengan memasukkan sediaan ke dalam xylol I, xylol II dan xylol III.

\subsubsection{Embeding dan Blocking}

Sediaan yang telah didehidrasi ditanam dalam cetakan yang telah diisi parafin cair setelah dari volumenya dan sebelum membeku ditambahkan lagi dengan parafin cair sampai penuh lalu didinginkan pada cold plate. Hasil cetakan yang sudah mengeras dikeluarkan dari cetakan dan blok yang diperoleh dapat disimpan dalam pendingin sampai siap untuk dipotong dengan mikrotom. 


\subsubsection{Pemotongan}

Sediaan dalam blok parafin dipotong menggunakan mikrotom dengan ketebalan 3-5 $\mu \mathrm{m}$ hingga berbentuk seperti pita dan diletakkan di atas permukaan air hangat untuk mencegah terjadinya lipatan pada pita. Sediaan selanjutnya diletakkan diatas gelas objek dan dikeringkan pada suhu ruang. Sediaan kemudiaan diwarnai dengan hematoksilin-eosin (HE).

\subsubsection{Pewarnaan Hematoksilin-Eosin (HE)}

Tahapan yang dilakukan dalam pewarnaan HE dimulai dengan proses deparafinisasi, yaitu penghilangan parafin dengan memasukkan preparat ke dalam seri larutan $x y / 0 / \mathrm{III}$, xylol II, dan $x y / 0 /$ I. Kemudian, dillakukan proses rehidrasi dengan memasukkan preparat ke dalam seri larutan alkohol absolut sampai alkohol $70 \%$ secara berurutan. Preparat direndam dalam air kran, kemudian dalam akuades. Preparat diwarnai dengan pewarna hematoksilin dilanjutkan dengan perendaman dalam akuades. Setelah itu, preparat diwarnai menggunakan eosin dan diikuti perendaman kembali dalam akuades. Setelah itu, dilakukan proses dehidrasi denganal alkohol bertingkat secara penjernihan menggunakan xylol. Sediaan ditutup dengan cover glass (mounting) dan siap untuk dilakukan pengamatan di bawah mikroskop.

\section{Hasil dan Pembahasan}

\subsection{Analisis in Vivo Kadar MDA dan SOD pada Paru-Paru Mencit}

Hasil penelitian menunjukkan bahwa pemberian asap rokok memiliki pengaruh terhadap kadar MDA dan SOD paruparu mencit. Pemberian paparan asap rokok dilakukan selama 14 hari. Hasil pengukuran kadar MDA dan SOD dapat dilihat pada Tabel 1.

Tabel 1. Kadar MDA dan SOD Paru-Paru Mencit

\begin{tabular}{lcc}
\hline \multicolumn{1}{c}{ Perlakuan } & Kadar MDA (ng/mL)* & Kadar SOD (U/mL) \\
\hline Kontrol Negatif (A1) & $1294,0 \pm 16,6^{\mathrm{b}}$ & $2,15 \pm 0,36^{\mathrm{b}}$ \\
Kontrol Positif (A2) & $1504,6 \pm 36,0^{\mathrm{a}}$ & $1,33 \pm 0,33^{\mathrm{c}}$ \\
Dosis 1 (57,6 mg/g bb/hari) (A3) & $1264,0 \pm 14,0^{\mathrm{bc}}$ & $1,98 \pm 0,25^{\mathrm{bc}}$ \\
Dosis 2 (115,2 mg/g bb/hari) (A4) & $1227,1 \pm 28,2^{\mathrm{cd}}$ & $3,19 \pm 0,08^{\mathrm{a}}$ \\
Dosis 3 (230,4 mg/g bb/hari) (A5) & $1194,63 \pm 40,4^{\mathrm{d}}$ & $3,82 \pm 0,27^{\mathrm{a}}$ \\
Dosis Vitamin E (0,86 mg/g bb/hari) (A6) & $1204,00 \pm 29,8^{\mathrm{cd}}$ & $3,66 \pm 0,54^{\mathrm{a}}$ \\
\hline
\end{tabular}

*(dinyatakan dalam mean \pm S.D), rata-rata diperoleh dari pengulangan $n=4$ kali. Huruf yang sama pada kolom menyatakan tidak berbeda nyata.

\subsection{Kadar Malonaldehida (MDA) pada Paru-Paru Mencit}

Pengukuran kadar MDA (Malondialdehida) paru mencit menunjukkan peningkatan kadar yang signifikan $(p<0,05)$ pada kontrol positif (A2) yaitu pemberian asap tanpa adanya terapi ekstrak dengan rerata $1504,6 \pm 36,0 \mathrm{ng} / \mathrm{mL}$ dibandingkan yang tidak diberi paparan asap rokok dengan rerata 1294,0 $16,6 \mathrm{ng} / \mathrm{mL}$. Peningkatan kadar MDA yang signifikan pada kontrol positif disebabkan karena stres oksidatif akibat paparan asap rokok tanpa diimbangi oleh pemberian antioksidan eksogen (dari luar tubuh) sehingga aktivitas peroksida lipid tetap berlanjut.

Peningkatan kadar MDA setelah diberi paparan asap rokok dibandingkan dengan kontrol negatif (A1) disebabkan adanya faktor peningkatan kadar peroksida lipid akibat senyawa radikal bebas asap rokok. Kenaikan kadar MDA menunjukan banyaknya jumlah radikal bebas. Asap rokok merupakan sumber radikal bebas yang dapat meningkatkan kadar MDA dalam tubuh [18]. Apabila tubuh sering terpapar asap rokok, maka radikal bebas di dalam tubuh akan bertambah banyak dan mengakibatkan adanya peningkatan kadar MDA. Kenaikan signifikan kadar MDA pada kelompok yang hanya dipapar asap memberikan rata-rata MDA 1504,6 $\pm 36,0 \mathrm{ng} / \mathrm{mL}$ dibandingkan kontrol negatif (A1) sebesar $1294,0 \pm 16,6 \mathrm{ng} / \mathrm{mL}$. Hal ini terbukti bahwa asap rokok mengandung radikal bebas dapat meningkatkan kadar MDA organ tubuh.

Peningkatan kadar MDA akibat radikal bebas dapat dicegah dengan pemberian senyawa antioksidan. Antioksidan ini dapat membantu menetralisir senyawa radikal bebas dan mencegah adanya kerusakan seluler sehingga dapat mencegah kenaikan kadar atau jumlah MDA. Hasil percobaan menunjukkan bahwa bahwa ada perbedaan yang nyata antara kelompok mencit yang diberi suspensi ekstrak etanol sirih merah dan vitamin E terhadap kontrol negatif. Hal ini dapat dikatakan bahwa ekstrak etanol daun sirih dan vitamin E mampu memberikan efek antioksidan yang signifikan dalam mencegah stres oksidatif. 
Pemberian ekstrak etanol daun sirih merah dan vitamin E mampu menekan kenaikan kadar MDA paru-paru mencit. Hal ini terbukti pada semua kelompok yang selain dipapar asap rokok yang diberi terapi ekstrak etanol daun sirih merah (A3, A4 dan A5) dan terapi vitamin E (A6) dibandingkan pada perlakuan A2 yang hanya diberi paparan asap rokok. Pemberian terapi ekstrak berbagai dosis dan vitamin E sebagai antioksidan dapat mencegah kerusakan membran sel paru-paru akibat paparan asap rokok sehingga senyawa SOD tidak mengalami penurunan. Pemberian ekstrak etanol daun sirih merah dan vitamin E mampu mengkondisikan jaringan paru-paru menuju kondisi normal. Menurut Osfor dkk [19], vitamin $E$ adalah senyawa penetralisir radikal bebas lipofilik dan bersifat antioksidan. Vitamin $\mathrm{E}$ dapat mencegah asap rokok untuk menjadi radikal bebas di dalam membran sel paru-paru sebelum menjadi peroksidasi lipid sehingga menjadi stabil dan tidak bersifat reaktif.

Kadar MDA jaringan paru-paru kelompok perlakuan yang mendapat ekstrak etanol (A3, A4 dan A5) dan vitamin $E$ (A6) lebih rendah dibandingkan dengan kontrol positif (A2). Hasil penelitian menunjukkan bahwa kelompok yang diberi paparan asap rokok dan disertai dengan pemberian ekstrak dan vitamin $\mathrm{E}$ menunjukkan adanya penuranan terhdap kadar MDA paru mencit karena oksidasi lipid pada asam lemak tidak jenuh rantai panjang (Polyunsaturated Fatty Acid/PUFA) dapat ditekan. Hasil sidik ragram dilanjutkan dengan BNJ pada taraf $5 \%$ menunjukkan bahwa pemberian terapi ekstrak etanol berbagai dosis dan terapi vitamin $E$ berpengaruh signifikan $(\alpha=0,05)$ terhadap penurunan kadar MDA paru-paru mencit yang dipapar asap rokok. Semakin besar dosis yang digunakan memberikan pengaruh yang signifikan terhadap penurunan kadar MDA.

Perlakuan dosis 2 ekstrak etanol $(115,2 \mathrm{mg} / \mathrm{g})$ dan vitamin $\mathrm{E}(0,86 \mathrm{mg} / \mathrm{g})$ memberikan hasil yang tidak berbeda dalam penurunan kadar MDA dibandingkan dengan kontrol positif. Kedua dosis ini juga memberikan penurunan kadar MDA dibawah kontrol negatif. Pada perlakuan dosis 1 (57,6 mg/g) dan dosis 3 (230,4 mg/g bb/hari) menurunkan kadar MDA yang berbeda dibandingkan dengan kontrol positif. Perlakuan dosis (A4) dengan dosis vitamin E (A6) memberikan hasil yang tidak berbeda. Semua perlakuan (dosis 1, 2, 3 dan vitamin E) memberikan pengaruh penurunan kadar MDA paru-paru mencit akibat paparan asap rokok. Semakin tinggi dosis ekstrak daun sirih merah dan vitamin $E$ yang diberikan penurunan kadar MDA paru-paru mencit juga semakin signifikan. Hal ini membuktikan ekstrak etanol daun sirih merah dan vitamin $\mathrm{E}$ mampu bekerja sebagai senyawa antioksidan. Dosis 3 mampu menurunkan kadar MDA yang paling baik dibandingkan dosis 1, 2, dan Vitamin E.

Penurunan kadar MDA paru-paru mencit dimungkinkan adanya senyawa golongan flavonoid dan fenolat dalam ekstrak. Hasil skrining fitokimia menyatakan ekstrak etanol daun sirih merah mengandung senyawa fenol dan flavonoid. Ghazemzadeh \& Ghasemzadeh [20] menyatakan golongan fenol merupakan senyawa antioksidan yang lebih efektif dibandingkan dengan vitamin $\mathrm{C}$ dan $\mathrm{E}$ serta karotenoid. Penurunan kadar MDA paru-paru mencit juga didukung penelitian Adyttia dkk [14] yang menyatakan pemberian ekstrak etanol $70 \%$ daun Premma cordifia pada tikus yang dipapar asap rokok mampu menurunkan kadar MDA yang signifikan dengan dosis $600 \mathrm{mg} / \mathrm{g} \mathrm{BB}$. Dugaan penurunan kadar MDA ini disebabkan oleh senyawa flavonoid yang ada pada ekstrak daun Premma cordifia. Selewa dkk [21] menyatakan senyawa flavonoid memiliki peran penting dalam antioksidan. Penelitian Zou dkk [22] dan Rasyid dkk [23] juga menyebutkan bahwa flavonoid merupakan senyawa antioksidan eksogen yang mampu untuk menurunkan kadar MDA.

\subsection{Kadar Superoksida Dismutase (SOD) pada Paru-Paru Mencit}

Peningkatan radikal bebas di dalam tubuh dapat menurunkan kadar SOD tubuh. Perlakuan pemberian ekstrak yang semakin tinggi dan vitamin E mampu meningkatkan aktivitas enzim SOD (Tabel 1). Perlakuan kontrol negatif (A1) memiliki kadar SOD sebesar 2,15 U/mL, setelah dipapar asap rokok menurun menjadi 1,33 U/mL (A2). Ini membuktikan paparan asap rokok mampu menurunkan enzim endogen dalam tubuh (SOD). Hasil sidik ragram dilanjutkan dengan BNJ pada taraf $5 \%$ menunjukkan terapi ekstrak berbagai dosis dan terapi vitamin $E$ memberikan pengaruh yang signifikan $(\alpha=0,05)$ terhadap kenaikan kadar SOD paru mencit yang dipapar asap rokok.

Asap rokok mampu menurunkan kadar SOD paru-paru mencit karena dalam asap rokok sebagai radikal terdapat senyawa-senyawa yang dapat merusak aktivitas enzim endogen yang berperan sebagai prooksidan. Penurunan kadar SOD akibat paparan asap rokok didukung penelitian Hritchu dkk [24] dimana dalam asap rokok yang mengandung nikotin dan diberikan pada tikus dapat menurunkan aktivitas SOD dan GPX. Penelitian Arumugam dkk [25] yang menyatakan penurunan tingkat SOD merupakan perwujudan dalam kerusakan hepatoseluler akibat adanya peningkatan produksi ROS (Reactive Oxygen Species) pada tingkat yang melebihi kemampuan akibat induksi etanol jangka panjang.

Penurunan kadar SOD paru-paru mencit akibat paparan asap rokok dapat dicegah dengan pemberian antioksidan dari ekstrak daun sirih merah. Pemberian ekstrak daun sirih merah berbagai dosis dan vitamin E dapat membantu kinerja enzim SOD dalam melawan senyawa radikal bebas sehingga penurunan kadar SOD dalam tubuh akibat asap rokok 
dapat dihambat. Komponen senyawa fenolat dan flavonoid ekstrak daun sirih merah dapat bekerja secara sinergis bersama enzim endogen SOD dalam menetralisir radikal bebas sehingga kadar SOD paru mengalami penurunan.

Analisis aktivitas enzim pada jaringan paru-paru menunjukkan kadar SOD masing-masing perlakuan memberikan nilai yang berbeda (Tabel 1). Peningkatan dosis ekstrak 56,7-230,4 mg/g bb/hari dan Vitamin E dosis 0,86 mg/g bb/hari menunjukkan perbedaan yang signifikan $(\mathrm{P}<0,05)$ pada kadar SOD paru-paru mencit dibandingkan kontrol positif. Semakin tinggi dosis ekstrak yang diberikan maka semakin tinggi aktivitas enzim SOD. Analisis ragram menunjukkan pemberian ekstrak dosis 2, 3 dan vitamin $\mathrm{E}(0,86 \mathrm{mg} / \mathrm{g})$ memiliki pengaruh (tidak berbeda) terhadap kenaikan SOD paru mencit, tetapi memberikan pengaruh yang signifikan dibandingkan dengan kontrol positif dalam menaikkan kadar SOD paru mencit.

Pemberian ekstrak dosis 1 (57,6 mg/g) berpengaruh signifikan terhadap kenaikan kadar SOD dibandingkan kontrol positif, tetapi tidak berbeda nyata terhadap atau kontrol negatif (A1). Perbedaan signifikan kadar SOD akibat terapi ekstrak dan vitamin E dibandingkan kontrol positif dikarenakan antioksidan endogen mampu mempertahankan aktivitasnya dalam tubuh, selain dari senyawa eksogen yang bekerja secara sinergi dengan senyawa endogen. Semakin besar dosis ekstrak, semakin tinggi kadar SOD.

Penurunan kadar SOD pada paru mencit setelah diberi paparan asap rokok dibandingkan dengan kontrol negatif disebabkan oleh adanya faktor peningkatan kadar peroksida lipid akibat adanya senyawa radikal bebas dari asap rokok. Oleh karena itu, penurunan kadar SOD dikatakan menunjukan banyaknya jumlah radikal bebas. Apabila tubuh sering terpapar asap rokok, maka radikal bebas di dalam tubuh akan bertambah banyak dan mengakibatkan adanya penurunan kadar SOD di dalam tubuh. Pada kelompok mencit A2 yang dipaparkan dengan asap rokok dan tanpa pemberian ekstrak serbuk daun sirih merah, penurunan kadar SOD lebih tinggi dibandingkan dengan kontrol perlakuan terapi ekstrak serbuk daun sirih merah dan obat vitamin $\mathrm{E}$.

Vitamin $\mathrm{E}$ bersifat antioksidan yang berperan dalam pencegahan radikal bebas karena dapat bereaksi dengan ROS dan radikal bebas lain. Dalam proses ini vitamin E berperan sebagai radikal bebas yang tidak reaktif sehingga dapat berikatan dengan elektron bebas dari radikal bebas reaktif lain. Pemberian paparan asap rokok dan terapi vitamin $\mathrm{E}$ menunjukkan hasil kadar SOD jaringan paru lebih tinggi bila dibandingkan dengan perlakuan A2 (pemberian paparan asap saja). Jadi, keberadaan antioksidan non-enzimatik (vitamin E) diperlukan untuk mengatasi stres oksidatif sehingga radikal bebas yang dibentuk akibat paparan asap rokok bisa di stabilkan dan tidak bersifat reaktif lagi.

Dalam penelitian ini belum diketahui jenis senyawa flavonoid dan senyawa fenolik yang berperan dalam menurunkan kadar MDA dan meningkatkan kadar SOD dalam paru. Senyawa alkaloid, saponin dan triterpenoid diduga memiliki aktivitas dalam menurunkan kadar MDA dan menaikkan kadar SOD paru mencit. Menurut Moura dkk [26] menyatakan bahwa senyawa alkaloid merupakan senyawa yang bertindak sebagai penangkap radikal bebas dan mencegah peroksidasi lipid pada hepatik mikrosomal. Senyawa alkaloid terutama indol, memiliki kemampuan menghentikan reaksi rantai radikal bebas. Senyawa radikal turunan dari amina ini memiliki tahap terminasi yang sangat lama. Senyawa alkaloid lain yang bersifat antioksidan adalah kafein yang dapat bertindak sebagai peredam radikal hidroksil.

\subsection{Histologi Jaringan Paru-Paru (Alveoli)}

Pengamatan sediaan preparat pada Gambar 1 menunjukkan adanya gambaran kerusakan alveolar berupa pembengkakan yang membentuk bula atau bintik-bintik hitam disertai dengan pembesaran duktus dan sakus alveolus. Gambaran mikroskopis jaringan paru pada preparat sediaan pada alveolus ditemukan pelebaran/pembengkakan dan adanya bintik-bintik hitam yang menebal. Ada perbedaan mikroskopis pada kelompok kontrol (positif dan negatif) dan kelompok perlakuan terapi ekstrak (A2, A3, A4 dan A5) serta terapi obat vitamin E (A6) akibat paparan asap rokok. Asap rokok memicu adanya stres oksidatif dan menimbulkan kerusakan pada muccociliary clearance, bulu getar dan makrofag alveolar tidak dapat berfungsi untuk membuang partikel atau berbagai bakteri yang masuk ke dalam paru-paru sehingga dapat meningkatkan terjadinya resiko infeksi/inflamasi paru-paru. Berdasarkan penelitian Banerjee dkk [27], asap rokok mengakibatkan stres oksidatif dan merusak alveolus paru-paru. Senyawa oksidan rokok menyebabkan kerusakan oksidatif yang signifikan pada protein mikrosom dan meningkatkan proteolisis akibat ketidakseimbangan antara protease dan anti protease. Proteolisis dan kerusakan oksidatif menyebabkan rusaknya dinding alveolus dan berujung pada rusaknya seluruh paru.

Penelitian pada kelompok kontrol positif dan perlakuan dosis ekstrak serta vitamin E terdapat gambaran kerusakan ringan. Hal ini disebabkan adanya terapi ekstrak dengan berbagai dosis dan vitamin $\mathrm{E}$, kerusakan yang minim juga disebabkan karena induksi asap yang kurang lama sehingga kerusakaan yang ditimbulkan kurang begitu signifikan. Gambaran kerusakan yang tidak signifikan disebabkan juga oleh adanya variabel luar yang tidak bisa dikendalikan seperti kondisi phisikologi dari mencit, daya imun mencit, daya regenerasi pada mencit dan lain-lain. 
Ada perbedaan yang nyata pada perlakuan $\mathrm{A} 1, \mathrm{~A} 2$ dan perlakuan ekstrak (dosis 1, 2 dan 3 ) dan dosis vitamin $\mathrm{E}$ (A6) terhadap mikroskopis jaringan alveoli paru mencit. Asap sebagai radikal merusak dinding alveoli paru-paru. Terapi ekstrak dan Vitamin E menyebabkan perubahan struktur organ paru terutama bagian alveoli menuju ke arah perbaikan atau normal. Radikal bebas asap rokok yang dipaparkan direduksi dan dicegah pembentukannya oleh antioksidan dari ekstrak daun sirih merah dan vitamin E. Senyawa antioksidan yang terdapat pada daun sirih merupakan golongan radical scavenging antioxidant yang memiliki fungsi sebagai senyawa yang berperan dalam mencegah (inhibitor) terbentuknya suatu radikal bebas dan mereduksi suatu radikal yang terbentuk. Potensi antioksidan dari ekstrak daun sirih merah dan vitamin $\mathrm{E}$ dapat mengurangi terjadinya stres oksidatif akibat paparan asap rokok dan mencegah kerusakan jaringan paru mencit.

Gambar A merupakan mikroskopis jaringan paru-paru (alveoli) yang tidak mendapatkan perlakuan apapun (kontrol negatif). Jaringan dalam keadaan normal, dinding alveoli terlihat kompak dan tidak terdapat peradangan atau pelebaran. Pada gambar B merupakan organ jaringan paru-paru (alveoli) dengan kondisi paparan asap rokok dan tidak diberikan terapi ekstrak daun sirih merah. Pada Gambar 1, Gambar mikroskopis (B) terlihat jelas pada sekitar dinding alveoli terjadi pembengkakan atau peradangan dan terdapat bintik-bintik hitam yang menebal.

Gambar C merupakan gambar mikroskopis paru-paru mencit (alveoli) dengan perlakuan pemberian terapi ekstrak dengan dosis 1 yaitu 57,6 mg/g bb/hari. Pemberian dosis ekstrak 1 memberikan gambaran mikroskopis yang berbeda terhadap permukaan dinding alveoli, pembengkakan dan pelebaran alveoli berkurang dibandingkan dengan kontrol positif (Gambar B), tetapi dinding permukaan masih terlihat tebal ditunjukkan dengan area sekitar dinding yang terlihat bintikbintik hitam yang tebal. Perbaikan pembengkakan dan pelebaran ini masih jauh dari kontrol negatif.

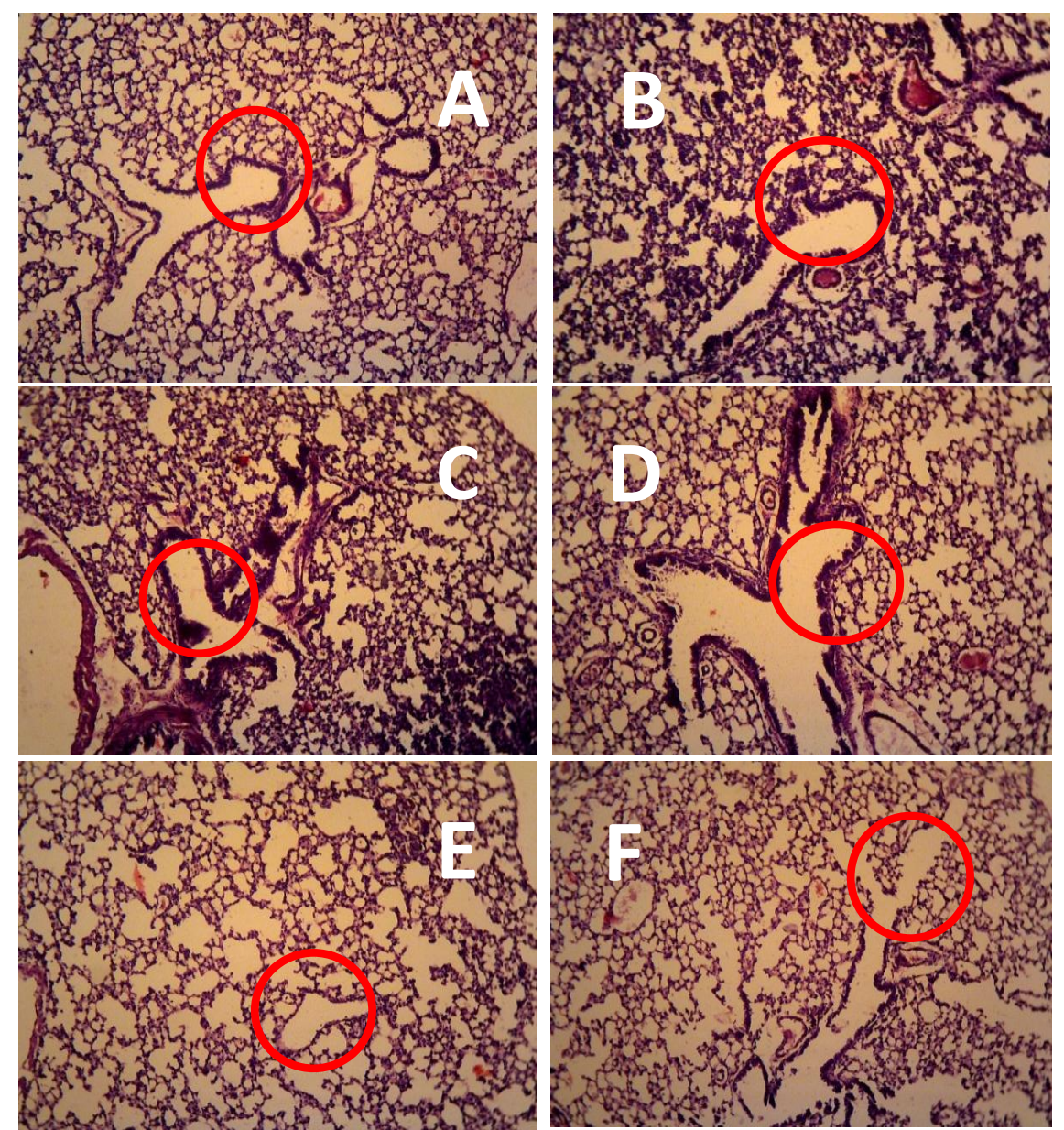

Gambar 1. Gambaran perbedaan mikroskopis pada jaringan paru-paru mencit (alveoli) perbesaran 100x. A (Kontrol Negatif), B (Kontrol Positif), C (Dosis 1), D (Dosis 2), E (Dosis 3) dan F (Dosis Vitamin E).

Kontrol ekstrak dengan dosis 2 (gambar D) sebesar 115,2 mg/g bb/hari memberikan hasil yang nyata terhadap dinding sel alveoli, pembengkakan dan perubahan (pelebaran) dinding sel berkurang. Lapisan dinding lebih terlihat bersih, bintik-bintik hitam kelihatan lebih menipis dibandingkan dengan kontrol positif (B) dan perlakuan dengan dosis 1 (gambar C). Pemberian ekstrak dosis 2 memberikan hasil yang nyata, tetapi masih memberikan visual di bawah kontrol negatif. Perlakuan ekstrak dosis 3 (Gambar E) yaitu 230,4 mg/g bb/hari memberikan hasil signifikan terhadap kondisi alveoli paru. 
Pemberian dosis 3 mengurangi radang dinding alveoli, kondisi dinding alveoli yang melebar dan penebalan dinding alveoli yang terlihat hitam berubah menjadi lebih tipis dan bersih, pembengkakan atau pelebaran lebih menurun dibandingkan dengan kontrol negatif $(A)$, kontrol positif $(B)$, perlakuan dosis 1 (C) dan perlakuan dosis 2 (D). Dosis 3 memberikan hasil yang paling baik. Kondisi paru tampak lebih baik dengan diameter alveolus yang tidak melebar dan kepadatan yang mendekati normal jika dibandingkan dengan kontrol negatif (Gambar B). Hal ini juga didukung oleh analisis MDA dan SOD yang memberikan hasil bahwa MDA kontrol negatif masih lebih tinggi dibandingkan dengan ekstrak dosis 3 (230,4 $\mathrm{mg} / \mathrm{g} \mathrm{bb} / \mathrm{hari})$, begitu pula dengan kadar SOD pada dosis 3 memberikan nilai yang lebih tinggi dibandingkan dengan kontrol negatif.

Gambar $\mathrm{F}$ adalah gambar mikroskopis paru (alveoli) perlakuan dosis Vitamin $\mathrm{E}(0,86 \mathrm{mg} / \mathrm{g} \mathrm{bb} / \mathrm{hari})$. Pemberian vitamin E menunjukkan hasil di bawah perlakuan pemberian ekstrak dosis 3, artinya perlakuan dosis 3 lebih memberikan pengaruh yang nyata dibandingkan dengan dosis Vitamin $\mathrm{E}$. Kontrol vitamin $\mathrm{E}$ memberikan pengaruh yang lebih baik dibandingkan dengan perlakuan dosis 1 dan dosis 2. Perlakuan pemberian dosis vitamin $\mathrm{E}$, secara mikroskopis dinding alveoli sudah menipis akibat pembengkakan. Radang pada alveoli berkurang, tetapi bagian dinding sel alveoli sedikit masih dalam warna hitam. Dapat disimpulkan bahwa dosis yang paling berpengaruh dalam perbaikan dinding sel paruparu, penurunan derajat pembengkakan dan penurunan pelebaran alveoli adalah dosis 3 sebesar 230,4 mg/g bb/hari.

Umumnya pembengkakan atau peradangan dan penebalan pada setiap tepi dinding alveolus lebih menipis dan bersih setelah adanya terapi ekstrak daun sirih merah dan vitamin E. Hal ini membuktikan bahwa terapi ekstrak serbuk daun sirih merah dan vitamin E mampu memperbaiki jaringan yang bengkak (melebar) dan membersihkan setiap tepi dari dinding alveoli pada paru mencit. Kemungkinan senyawa yang berperan adalah golongan senyawa flavonoid dan fenolat. Senyawa flavonoid dapat digunakan dalam terapi inflamasi sel. Hal ini didukung dengan pernyataan Kalt [28] senyawa golongan flavonoid dapat mengramankan sel dari serangan senyawa ROS. Berdasarkan gambaran mikroskopis pada Gambar 1, terlihat bahwa peradangan atau pembengkakan sel alveoli mengalami penipisan atau pengecilan dan daerah dinding alveoli terlihat lebih bersih.

Pemberian terapi ekstrak daun sirih merah dan Vitamin $\mathrm{E}$ dapat mengurangi bintik-bintik hitam akibat akumulasi radikal asap sehingga terlihat lebih tipis dan lebih bersih. Penelitian Comalada dkk. [29] menyatakan bahwa flavonoid dapat berperan sebagai antioksidan melalui aktivitasnya sebagai scavenger dan Lenzatti dkk. [30] menyebutkan bahwa flavonoid memiliki fungsi dalam inhibitor protease. Dengan adanya senyawa flavonoid, asap rokok yang mengandung senyawa radikal masuk ke dalam tubuh akan memicu proses inflamasi dan menyebabkan terjadinya ketidakseimbangan antara protease dengan antiprotease yang terdapat pada jaringan alveolar paru-paru sehingga menyebabkan adanya degradasi pada jaringan paru-paru. Keberadaan senyawa flavonoid dapat menghambat kerja protease dalam mengelastisitas organ paru-paru sehingga organ tersebut akan mengalami perbaikan dari adanya peradangan atau pelebaran alveolus.

\section{Kesimpulan}

Uji ekstrak secara in vivo, ekstrak etanol $90 \%$ memberikan pengaruh terhadap penurunan kadar MDA dan kenaikan kadar SOD organ jaringan paru-paru mencit akibat paparan asap rokok. Dosis ekstrak yang optimal untuk terapi dalam mencit stress oksidatif yang dipapar asap rokok adalah 230,4 mg/g BB/hari yang mampu menurunkan kadar MDA, menaikan kadar SOD, mengurangi peradangan dinding sel alveoli dan memperbaiki dinding sel alveoli.

\section{Daftar Pustaka}

[1] D. M. Burns, "Nicotine Addiction," in Harrison's Principles of Internal Medicine, 16th ed. New York: McGraw-Hill Education, 2004.

[2] R. F. Tyndale \& E. M. Sellers, "Variable CYP2A6-Mediated Nicotine Metabolism Alters Smoking Behavior and Risk," Drug Metabolism and Disposition, vol. 29, no. 4, pp. 548-552, 2001.

[3] J. Hukkanen, P. Jacob, \& N. L. Benowitz, "Metabolism and Disposition Kinetics of Nicotine," Pharmacological Reviews, vol. 57, no. 1, pp. 79-115, 2005.

[4] M. Pignone \& R. Salazar, "Disease Prevention and Health Promotion," in Current Medical Diagnosis and Treatment, 47th ed. New York: McGraw-Hill, 2008.

[5] J. Fowles \& M. Bates, "The Chemical Constituents in Cigarettes and Cigarette Smoke: Priorities for Harm Reduction, Epidemology and Toxicology Group," ESR: Kenepuru Science Center, Porirua, New Zealand, 2000.

[6] I. Fidrianny, I. Supradja, \& A. A. Soemardji, "Analisis Nikotin dalam Asap dan Filter Rokok," Acta Pharmaceutica Indonesia, vol. 29, no. 3, pp. 100-104, 2004.

[7] K. Aoshiba \& A. Nagai, "Oxidative Stress, Cell Death, and Other Damage to Alveolar Epithelial Cells Induced by Cigarette Smoke," Tobacco Induced Disease, vol. 1, no. 3, pp. 219-226, 2003. 
[8] B. Halliwell \& J. M. C. Gutteridge, Free Radicals in Biology and Medicine, 4th ed. New York: Oxford University Press, 2006.

[9] D. S. Beattie, "Bioenergetics and Oxidative Metabolism," in Textbook of Biochemistry with Clinical Correlations, 5th ed. New York: Wiley-Liss, 2002.

[10] S. Khotimah, "Pengaruh Pemberian Ekstrak Jinten Hitam (Nigella sativa) terhadap Kadar GSH Paru dan Hepar Tikus Wistar yang Dipapar Asap Rokok: Penelitian Eksperimental Laboratoris," Tesis, Pascasarjana IImu Kedokteran Dasar, Universitas Airlangga, Surabaya, 2005.

[11] G. C. Cochrane, "Cellular Injury by Oxidants," American Journal of Medicinal, vol. 30, no. 91(3C), pp. 23S-30S, 1991.

[12] Z. Rasheed, N. Akhtar, A. N. Anbazhagan, S. Ramamurthy, M. Shukla, \& T. M. Haqqi, "Polyphenolic-rich Pomegranate Fruits Extract (POMx) Suppresses PMACl-induced Expression of Pro-Inflammatory Cytokines by Inhibiting the Activation of MAP Kinase and NF-kB in Human Ku812 Cells," Journal of Inflammation, vol. 6, no. 1, 2009.

[13] O. M. Prameswari \& S. B. Widjanarko, "Uji Efek Ekstrak Air Daun Pandan Wangi terhadap Penurunan Kadar Glukosa Darah dan Histopatologi Tikus Diabetes," Jurnal Pangan dan Agroindustri, vol. 2, no. 2, pp. 16-27, 2014.

[14] A. Adyttia, E. K. Untari, \& S. Wahdaningsih, "Efek Ekstrak Etanol Daun Premma cordifolia terhadap Malondialdehida Tikus yang Dipapar Asap Rokok," Pharmaceutical Sciences \& Research, vol. 1, no. 2, pp. 104-115, 2014.

[15] N. A. Sholichah, Aulanni'am, \& C. Mahdi, "Efek Terapi Ekstrak Air Daun Kedondong (Lannea coromandelica) terhadap Kadar Malondialdehid (MDA) dan Aktivitas Protease pada lleum Tikus Putih (Rattus norvegicus) Inflammatory Bowel Disease (IBD) Akibat Paparan Indometasin," Veterinaria Medika, vol. 5, no. 3, pp. 187-194, 2012.

[16] M. A. Abdulla, F. H. Al-Bayaty, L. T. Younis, \& M. I. A. Hassan, "Anti-ulcer Activity of Centella asiatica Leaf Extract against Ethanol-Induced Gastric Mucosal Injury in Rat," Journal of Medicinal Plants Research, vol. 4, no. 13, pp. 1253-1259, 2010.

[17] M. Muntiha, "Teknik Pembuatan Preparat Histopatologi dari Jaringan Hewan dengan Pewarnaan Hemaktoksilin dan Eosin (H\&E)," Temu Teknis Fungsional Non Peneliti, pp. 156-163, 2001.

[18] Y. Yueniwati \& M. Ali, "Pengaruh Paparan Asap Rokok Kretek terhadap Peroksidasi Lemak dan Sistem Proteksi Superoksid Dismutase Hepar Tikus Wistar," Jurnal Kedokteran Yarsi, vol. 12, no. 1, pp. 85-92, 2004.

[19] M. M. H. Osfor, H. S. Ibrahim, Y. A. Mohamed, S. M. A. A. S. Abd El Azeem, \& A. M. Hegazy, "Effect of Alpha Lipoic Acid and Vitamin E on Heavy Metals Intoxication in Male Albino Rats," Journal of America Science, vol. 6, no. 8, pp. 56-63, 2010.

[20] A. Ghasemzadeh \& N. Ghasemzadeh, "Review Flavonoids and Phenolic Acids: Role and Biochemical Activity in Plants and Human," Journal of Medicinal Plants Research, vol. 5, no. 31, pp. 6697-6703, 2011.

[21] W. Selewa, M. R. J. Runtuwene, \& G. Citraningtyas, "Kandungan Flavonoid dan Kapasitas Antioksidan Total Ekstrak Etanol Daun Binahong (Anredera cordifolia (Ten.) Steenis," Pharmacon, vol. 2, no. 1, pp. 18-22, 2013.

[22] Y. Zou, Y. Lu, \& D. Wei, "Hypercholesterolemic Effects of a Flavonoid-rich Extract of Hypericum perforatum L. in Rats Fed a Cholesterol-rich Diet," Journal of Agricultural and Food Chemistry, vol. 53, pp. 2462-2466, 2005.

[23] H. N. Rasyid, Y. D. Ismiarto, \& R. Prasetia, "The Efficacy of Flavonoid Antioxidant from Chocolate: Bean Extract: Prevention of Myocyte Damage Cause by Reperfusion Injury in Predominantly Anaerobic Sports," Malaysian Orthopedic Journal, vol. 6, no. 3, pp. 3-6, 2012.

[24] L. Hritcu, A. Ciobica, \& L. Gorgan, "Nicotine-induced Memory Impairment by Increasing Brain Oxidative Stress," Central European Journal of Biology, vol. 4, no. 3, pp. 335-342, 2009.

[25] S. Arumugam, P. Srinivasan, S. Manikandaselvi, \& R. Thinagargab, "Protective Effect and Antioxidant Role of Achyranthus aspera L. againts Ethanol-induced Oxidative Stress in Rats," International Journal of Pharmacy and Pharmaceutical Sciences, vol. 4, no. 3, pp. 280-284, 2012.

[26] D. J. Moura, M. F. Richter, J. M. Boeira, J. A. P. Henriques, \& J. Saffi, "Antioxidant Properties of $\beta$-Carboline Alkaloids are Related to Their Antimutagenic and Antigenotoxic Activities," Mutagenesis, vol. 22, no. 4, pp. 293-302, 2007.

[27] S. Banerjee, P. Maity, S. Mukherjee, A. K. Sil, K. Panda, D. Chattopadhyay, \& I. B. Chatterjee, "Black Tea Prevents Cigarette Smoke-induced Apoptosis and Lung Damage," Journal of Inflammation, vol. 4, no. 3, 2007.

[28] W. Kalt, "Health Functional Phytochemicals of Fruits," Horticultural Reviews, vol. 27, 2002.

[29] M. Comalada et al., "Inhibition of Pro-inflammatory Markers in Primary Bone Marrow-derived Mouse Macrophages by Naturally Occurring Flavonoids: Analysis of the Structure-Activity Relationship," Biochemical Pharmacology, vol. 72, no. 8, pp. 1010-1021, 2006.

[30] M. Lenzatti et I., "Mate Tea Ameliorates Ebmphysema in Cigarette Smoke-exposed Mice," Experimental Lung Research, vol. 37, no. 4, pp. 246-257, 2011. 